\title{
PENGARUH KARAKTERISTIK PERUSAHAAN TERHADAP RETURN SAHAM JAKARTA ISLAMIC INDEKS DI BURSA EFEK INDONESIA
}

\section{THE EFFECT OF COMPANY CHARACTERISTICS TO STOCK RETURN OF JAKARTA ISLAMIC INDEX IN INDONESIA STOCK EXCHANGE}

\author{
Windari \\ Fakultas Ekonomi dan Bisnis Islam IAIN Padangsidimpuan \\ Jl. H.T. Rizal Nurdin Km. 4,5 Sihitang, Padangsidimpuan 22733 \\ e-mail:wwindariok@gmail.com
}

Naskah diterima 15 Mei 2018, di-review 01 Juni 2018, disetujui 22 Juni 2018

\begin{abstract}
This study aims to determine the Influence of Company Characteristics on Stock Return of Jakarta Islamic Index (JII) in Indonesia Stock Exchange. The method of data collection wasdocuments of company records. The data used in this study was secondary data in the form of stock financial statements of 40 companies incorporated in JII.The data was analyzed through multiple linear regression analysis and hypothesis test with $t$ and $F$ test. The result reveals company characteristics (EPS, PBV, PER, DER) influence stock return. It clearly seen from $F_{\text {count }}>F_{\text {table }}(21,52257>2,34)$. This research finding is in accordance with the previous researches. Then, partially, it shows the variables consisting of EPS (X1), and PBV (X2) influence the stock return with significance level below 0.05. Another variable that has no effect is PER (X3) with0,2063 significance level and DER (X4) with 0,8467 significance level.
\end{abstract}

Keywords: stock return, earning persare, price to book value, price earning ratio, debt to equity ratio

\begin{abstract}
Abstrak: Penelitian ini bertujuan untuk mengetahui pengaruh karakteristik perusahaan terhadap Return Saham Indeks Islam Jakarta di Bursa Efek Indonesia. Metode pengumpulan data adalah dengan dokumentasi, menggunakan salinan arsip atau catatan perusahaan. Berdasarkan sumbernya, data yang digunakan dalam penelitian ini adalah data sekunder berupa laporan keuangan saham yang tergabung dalam JII sebanyak 40 perusahaan, model analisis yang digunakan dalam penelitian ini adalah regresi linier berganda.. Analisis regresi linier berganda dan uji hipotesis dengan uji t dan F. Hasil yang diperoleh secara simultan variabel Karakteristik Perusahaan (EPS, PBV, PER, DER) terhadap return saham dapat diterima secara keseluruhan dimana nilai $\mathrm{F}$ hitung adalah 21,52257, dengan tingkat signifikansi $0,000 .=0,05$ ) adalah 2,34. Sementara F tabel pada tingkat kepercayaan 95\% (Oleh karena itu, pada kedua perhitungan $\mathrm{F}$ hitung $>\mathrm{F}$ tabel $(21,52257>2,34)$, ini memberikan kesimpulan yang mendukung penelitian berbagai penelitian sebelumnya. Secara parsial menunjukkan variabel yang terdiri dari EPS (X1), PBV (X2), berpengaruh terhadap return saham dengan tingkat signifikansi di bawah 0,05. Dengan demikian area penerimaan hipotesis berada di luar area penerimaan $\mathrm{H} 0$. Variabel lain yang tidak berpengaruh adalah PER (X3) dengan signifikansi 0,2063 dan DER (X4) dengan signifikansi 0,8467.
\end{abstract}

Kata kunci: Return Saham, Earning Persare, Price to Book Value, Price Earning Ratio, Rasio Hutang terhadap Ekuitas

\section{PENDAHULUAN}

P asar modal suatu sarana bagi perusahaan maupun institusi lain dalam kegiatan berinvestasi, atau lembaga yang menghubungkan investor (pemilik modal) dengan perusahaan yang membutuhkan tambahan modal, sehingga pasar modal memiliki peranan penting dalam kelangsungan hidup perusahaan.

Dilihat dari sisi syariah Islam, pasar modal merupakan satu produk muamalah. Transaksi di dalam pasar modal menurut syari'ah tidak dilarang 
(dibolehkan) sepanjang tidak terdapat transaksi yang bertentangan dengan ketentuan yang telah digariskan oleh syariah Islam. Hal ini disebabkan bahwa perkembangan ekonomi suatu negara tidak lepas dari perkembangan pasar modal. Dimana pasar modal berdasarkan prinsip syariah telah dikembangkan di berbagai negara. Oleh karena investasi di pasar modal tidak selalu sesuai dengan ketentuan syari'ah Islam, maka berinvestasi di pasar modal harus dilakukan dengan sangat selektif dan dengan sangat hati-hati, sehingga tidak masuk dalam investasi yang bertentangan dengan syariah (Nazir, dkk, 2004: 32).

Investor yang menanamkan modalnya pada perusahaan tertentu sudah pasti mengharapkan return (keuntungan). Return saham itu sendiri adalah hasil yang diperoleh dari investasi dengan cara menghitung selisih harga saham periode berjalan dengan periode sebelumnya. Sebenarnya hampir semua investasi mengandung unsur ketidakpastian atau risiko. Pemodal tidak tahu dengan pasti hasil yang akan diperoleh dari investasi yang dilakukannya. Dalam keadaan semacam ini dikatakan bahwa pemodal tersebut menghadapi risiko dalam investasi yang dilakukannya.

Dalam berinvestasi, semakin besar risiko suatu sekuritas, semakin besar return yang diharapkan. Sebaliknya juga semakin kecil return yang diharapkan, semakin kecil pula risiko yang harus ditanggung.

Apabila return saham dari suatu perusahaan meningkat yang disebabkan oleh laba perusahaan yang meningkat berarti tingkat kesehatan perusahaan meningkat, dengan kata lain bahwa dengan adanya kenaikan return saham, investor akan berbondong-bondong untuk memiliki saham perusahaan tersebut. Sedangkan bila return saham dari suatu perusahaan dikatakan moderat, ini berarti return saham yang didapat investor tersebut tetap, hal ini berakibat investor yang ingin menanamkan modalnya tidak terlalu berambisi karena tidak ada kemajuan atau peningkatan. Bila return saham suatu perusahaan menurun akan berakibat investor akan mendapatkan hasil yang terus menurun akibatnya investor tidak mau menanamkan modalnya pada perusahaan tersebut.

Dalam mengetahui tingkat kesehatan perusahaan sebelum investor menanamkan modalnya perlu untuk menganalisis tingkat kesehatan dan kinerja suatu perusahaan tersebut dengan mempertimbangkan karakteristik perusahaan dan ekonomi makro dalam strategi investasi yang akan dilakukan oleh investor. Karakteristik perusahaan digolongkan ke dalam beberapa hal, yakni rasio utang terhadap modal sendiri (debt to equity ratio), rasio harga saham terhadap nilai buku (price to book value), rasio profitabilitas, ukuran perusahaan, tipe perusahaan, deviden payout ratio, cyclicality, price earning ratio, cash ratio, debt to ratio, long time debt to equity ratio, total asset turn offer, fixed turn offer, account recevable turn offer, inventory turn offer, average collection periode, days sales in inventory, deviden yeild, deviden per share, earning per share (Rangkuti, 2001: 213).

Karakteristik perusahaan yang digunakan dalam penelitian ini ada empat karakteristik. Peneliti ingin melihat dari segi earning per share, price to book value, price earning ratio, debt to 
equity ratio, untuk dijadikan bahan pertimbangan bagi para investor dalam melakukan investasi di pasar modal.

Penelitian mengenai return saham yang dipengaruhi oleh variabel-variabel karakteristik perusahaan, dan ekonomi makro merupakan hal yang menarik untuk dilakukan karena diharapkan dapat menjadi rujukan bagi investor dalam menentukan strategi investasi yang akan dilakukan khususnya penanaman modal di JII yang saham-sahamnya sesuai dengan syariah Islam. Penelitian ini mengambil objek pada saham JII, karena menggambarkan sekelompok saham pilihan yang memenuhi kriteria tertentu sesuai dengan syariah Islam. Berdasarkan uraian latar belakang penelitian di atas, penulis merumuskan permasalahan sebagai berikut: Apakah terdapat pengaruh karakteristik perusahaan (earning per share, price to book value, price earning ratio, debt to equity ratio) terhadap Return saham JII secara simultan dan parsial di BEI?

\section{METODE PENELITIAN}

Populasi dalam penelitian ini adalah sahamsaham JII yang terdaftar di BEI selama periode 2011 - 2015. Dalam penentuan sampel peneliti menggunakan purposive sampling yaitu dengan cara menunjukkan langsung pada suatu populasi berdasarkan kriteria yang dimiliki sampel, dengan tujuan agar diperoleh sampel yang representatif sesuai dengan kriteria yang ditentukan. Adapun kriteria pemilihan sampel yang digunakan adalah:

1. Saham yang terus-menerus muncul dalam kelompok JII di Bursa Efek Indonesia selama periode 2011-2015.
2. Perusahaan yang berlaba dan membagikan deviden

3. Berturut-turut mengeluarkan laporan keuangan selama periode pengamatan dari 2011-2015

Metode pengumpulan data yaitu dengan dokumentasi, menggunakan salinan arsip atau catatan perusahaan. Berdasarkan sumbernya, data yang digunakan dalam penelitian ini adalah data sekunder berupa laporan keuangan sahamsaham yang tergabung dalam JII dan Laporan Bank Indonesia mengenai kurs valuta asing dan inflasi yang diperoleh dari website Bank Indonesia. Data variabel-variabel karakteristik perusahaan diperoleh dari Indonesian Capital Market Directory (ICMD), website mengenai pasar modal, Bank Indonesia. Data-data tersebut diperoleh dari laporan tahunan perusahaaanperusahaan yang terdaftar di Bursa Efek Indonesia yang memenuhi kriteria di atas.

Model analisis yang digunakan dalam penelitian ini adalah regresi linier berganda. Dengan menggunakan program komputer eview untuk memperoleh hasil yang akurat dan tepat, serta pengolahan data dilakukan dengan cepat. Adapun uji yang dilakukan untuk penelitian ini adalah uji asumsi klasik, yaitu normalitas, autokorelasi, dan multikolinealiritas. Analisis regresi linier berganda serta uji hipotesis dengan uji T dan F.

\section{PEMBAHASAN DAN HASIL}

\section{Jakarta Islamic Index (JII)}

Dalam rangka mengakomodir investor yang tertarik berinvestasi, BEI dan Danareksa 
Investment Management (DIM) meluncurkan sebuah indeks yang didasarkan pada Syariah Islam, dikenal dengan nama Jakarta Islamic Index (JII).

JII diluncurkan pada tanggal 3 Juli 2000. JII dihitung mundur hingga tanggal 1 Januari 1995 sebagai hari dasar dengan nilai dasar 100. JII terdiri dari 30 saham yang sesuai dengan Syariah Islam. Dewan Pengawas Syariah PT DIM terlibat dalam menetapkan kriteria saham-saham yang masuk dalam JII.

Jadi secara khusus saham-saham yang masuk kriteria JII adalah saham-saham yang operasionalnya tidak mengandung unsur ribawi, permodalan perusahaan juga bukan mayoritas dari hutang. Maka saham-saham JII ini pada umumnya mempunyai struktur modal yang sehat dan tidak terbebani bunga hutang berlebihan, dengan kata lain debt-to equity rasionya masih proporsional sehingga sangat menjanjikan untuk investasi jangka menengah-panjang.

Pengelolaannya juga dinilai transparan dan kredibel serta menghormati pemegang sahamnya. Saham-saham anggota JII sebagian besar juga anggota indeks lainnya hanya ada sedikit kriteria syariah tersebut. Indeks JII seperti indeks modern lainnya, bersifat dinamis dalam arti secara periodik di-update agar senantiasa responsif dengan pergerakan pasar dan sesuai dengan syariah.

Dalam sejarah, lahirnya ekonomi Islam pada masa-masa sekarang ini lebih disebabkan oleh dua faktor. Pertama, faktor ajaran agama yang melarang riba dan menghalalkan jual beli. Kedua, timbulnya surplus dolar dari negara-negara penghasil dan pengekspor minyak dari Timur Tengah dan negara Islam di mana mereka pada akhirnya membutuhkan institusi keuangan Islam untuk menyimpan dana mereka.

Di Indonesia ekonomi syariah mulai dikenal sejak berdirinya Bank Muamalat Indonesia pada tahun 1991. Selanjutnya ekonomi berbasis syariah di Indonesia ini mulai menunjukkan perkembangan yang menggembirakan. Pada dasarnya, sebagai negara yang mayoritas penduduknya beragama Islam, sudah menjadi kewajiban bagi umat Islam Indonesia untuk menerapkan ekonomi syariah sebagai bukti ketaatan dan ketundukan masyarakat pada Allah Swt dan Rasulnya. Penerapan hukum syariah bukan hanya terbatas pada bank-bank saja, tapi sudah menjalar ke bisnis asuransi, bisnis multilevel marketing, koperasi bahkan ke pasar modal.

Para investor muslim kini tidak perlu susahsusah lagi untuk menanamkan modalnya pada suatu jenis usaha, karena Bursa Efek Indonesia sudah memiliki Jakarta Islamic Indeks yang memuat indeks saham yang masuk kategori halal. Meski demikian, harus diakui bahwa selama lebih dari satu dasawarsa di tengah makin berkembangnya institusi ekonomi berbasiskan hukum Islam, masih banyak umat Islam di Indonesia yang belum memahami dan mengenal perekonomian yang berbasis syariah secara menyeluruh.

Dalam rangka mengembangkan pasar modal syariah, PT Bursa Efek Indonesia (BEI) bersama dengan PT Danareksa Investment Management (DIM) meluncurkan indeks saham yang dibuat berdasarkan syariah Islam, yaitu Jakarta Islamic 
Indeks (JII). Jakarta Islamic Indeks terdiri atas 30 jenis saham yang dipilih dari saham-saham yang sesuai dengan syariah Islam.

Jakarta Islamic Indeks dimaksudkan untuk digunakan sebagai tolak ukur (benchmark) untuk mengukur kinerja suatu investasi pada saham dengan basis syariah. Melalui indeks diharapkan dapat meningkatkan kepercayaan investor untuk mengembangkan investasi dalam ekuiti secara syariah.

JII telah dikembangkan sejak tanggal 3 Juli 2000. Pembentukan instrumen syariah ini untuk mendukung pembentukan Pasar Modal Syariah yang kemudian diluncurkan di Jakarta pada tanggal 14 Maret 2003. Mekanisme Pasar Modal Syariah meniru pola serupa di Malaysia yang digabungkan dengan bursa konvensional seperti Bursa Efek Jakarta dan Bursa Efek Surabaya.

Indeks harga saham yang lebih spesifik dengan dasar ajaran Islam yaitu Jakarta Islamic Indeks (JII) dengan anggota 30 saham pilihan. Ke-30 saham anggota JII tersebut dinilai memenuhi syarat yang ditetapkan oleh Dewan Syariah Nasional (DSN) MUI. Intinya saham-saham yang masuk ke dalam JII-30 harus memenuhi unsur yang sama dengan indeks lainnya kecuali unsur haram dalam pandangan MUI. Unsur haram yang disyaratkan DSN MUI pada umumnya terkait dengan: alkohol, perjudian, produksi dengan bahan baku babi, pornografi, jasa keuangan dan asuransi konvensional.

Keenam fatwa-fatwa DSN MUI tahun 2004 tersebut mengatur prinsip-prinsip syariah di bidang pasar modal yang menyatakan bahwa suatu sekuritas/ efek di pasar modal dipandang telah memenuhi prinsip-prinsip syariah apabila telah memperoleh pernyataan kesesuaian syariah secara tertulis dari DSN-MUI.

Maka sejak keberadaannya 1995, dan berbagai penyempurnaan tahun 2000 dan 2003, saham-saham JII menunjukkan kinerja yang baik dan mampu bersaing dengan saham-saham dari anggota indeks lainnya. Perkembangan JII selama periode Januari 2011 sampai dengan Desember 2015. terlihat pada tabel berikut ini :

Tabel 1.

Pergerakan Indeks Saham JII periode 2011 - 2015

\begin{tabular}{|l|l|l|}
\hline NO & \multicolumn{1}{|c|}{ TAHUN } & \multicolumn{1}{c|}{ JII } \\
\hline 1. & $2011 \quad$ & 199,749 \\
\hline 2. & 2012 & 311,281 \\
\hline 3. & 2013 & 216,189 \\
\hline 4. & 2014 & 417,182 \\
\hline 5. & 2015 & 400,432 \\
\hline
\end{tabular}

Sumber: Data diolah, 2016

Selama tahun 2011 indeks saham JII berada pada posisi 199,749, pada tahun 2012 naik menjadi 311,281, kemudian menurun ke posisi 216,189 pada tahun 2013 , dan menunjukkan kenaikan pada tahun 2014 ke posisi 417,182, dan menurun ke posisi 400,432 tahun 2015.

\section{Hasil Uji Model Penelitian}

Model penaksiran yang dipakai pada penelitian ini berdasarkan Model Regressi Data Panel: Fixed Effect Model (FEM) dengan cross-section weights karena menghasilkan hasil estimasi yang lebih baik dibandingkan FEM biasa. 
Tabel 2.

Hasil Taksiran Model Regressi Pooled -Cross-Section Weights

Dependent Variable: RETURN?

Method: GLS (Cross Section Weights)

Date: 03/07/16 Time: 04:14

Sample: 20112015

Included observations: 5

Number of cross-sections used: 8

Total panel (balanced) observations: 40

Convergence achieved after 36 iterations

\begin{tabular}{|c|c|c|c|c|}
\hline Variable & Coefficient & Std. Error & t-Statistic & Prob. \\
\hline EPS? & 0.000156 & 5.86E-05 & 2.662798 & 0.0131 \\
\hline PBV? & -0.109740 & 0.042158 & -2.603085 & 0.0151 \\
\hline PER? & 0.018832 & 0.014528 & 1.296318 & 0.2063 \\
\hline DER? & -0.032933 & 0.168648 & -0.195275 & 0.8467 \\
\hline \multicolumn{5}{|l|}{ Fixed Effects } \\
\hline AT-C & -1.349174 & & & \\
\hline$-B R-C$ & -1.276950 & & & \\
\hline IITP-C & -2.264794 & & & \\
\hline - IN-C & -1.603743 & & & \\
\hline _KF-C & -1.414120 & & & \\
\hline$-\mathrm{TBB}-\mathrm{C}$ & -1.463375 & & & \\
\hline$-\mathrm{TI}-\mathrm{C}$ & -2.197427 & & & \\
\hline $\mathrm{UI}-\mathrm{C}$ & -0.156845 & & & \\
\hline \multicolumn{5}{|l|}{ Weighted Statistics } \\
\hline R-squared & 0.914975 & \multicolumn{2}{|c|}{ Mean dependent var } & 1.312440 \\
\hline Adjusted R-squared & 0.872463 & \multicolumn{2}{|c|}{ S.D. dependent var } & 2.173904 \\
\hline S.E. of regression & 0.776352 & \multicolumn{2}{|c|}{ Sum squared resid } & 15.67078 \\
\hline F-statistic & 21.52257 & \multicolumn{2}{|c|}{ Durbin-Watson stat } & 2.409170 \\
\hline Prob(F-statistic) & 0.000000 & & & \\
\hline \multicolumn{5}{|l|}{ Unweighted Statistics } \\
\hline R-squared & 0.408258 & \multicolumn{2}{|c|}{ Mean dependent var } & 0.696500 \\
\hline Adjusted R-squared & 0.112387 & \multicolumn{2}{|c|}{ S.D. dependent var } & 0.824041 \\
\hline S.E. of regression & 0.776356 & \multicolumn{2}{|c|}{ Sum squared resid } & 15.67094 \\
\hline Durbin-Watson stat & 2.980019 & & & \\
\hline
\end{tabular}

Data diolah dengan EViews 4,1

\section{Pengujian Hipotesis}

Pengujian goodness of fit dilakukan untuk menentukan kelayakan suatu model regresi. Variabel penelitian yang digunakan pada penelitian ini lebih dari dua variabel maka kelayakan tersebut dapat dilihat dari nilai Adjusted $R$ Square. Nilai Adjusted $R$ Square yang diperoleh dari hasil pengolahan data dapat dilihat pada Tabel 4.3 di bawah ini:

Tabel 3.

Pengujian Goodness of Fit

\begin{tabular}{|l|l|l|l|}
\hline R-squared & 0.914975 & Mean dependent var & 1.312440 \\
\hline Adjusted R-squared & 0.872463 & S.D. dependent var & 2.173904 \\
\hline S.E. of regression & 0.776352 & Sum squared resid & 15.67078 \\
\hline F-statistic & 21.52257 & Durbin-Watson stat & $\mathbf{2 . 4 0 9 1 7 0}$ \\
\hline Prob(F-statistic) & 0.000000 & & \\
\hline
\end{tabular}

Sumber :Hasil Olahan Eview

18| Windari 
Nilai Adjusted R Square pada Tabel 4.3 diatas sebesar 0,8724. Hal ini menunjukkan bahwa $87,24 \%$ variabel Return Saham dapat dijelaskan oleh variabel Karakteristik Perusahaan (EPS, PBV, PER, DER sedangkan sisanya sebesar 12,76 $\%$ dipengaruhi oleh variabel lain yang tidak dijelaskan oleh model penelitian ini.

Untuk menguji apakah parameter koefesien Adjusted $R^{2}$ signifikan atau tidak maka dilakukan pengujian dengan bantuan alat uji statistik metode Fisher (Uji F) dengan tingkat keyakinan (confidentlevel) sebesar $95 \%$. Kriteria pengujian yang digunakan adalah apabila $\mathrm{F}_{\text {hitung }}>\mathrm{F}_{\text {tabel }}$ maka
Ho ditolak; dan apabila $\mathrm{F}_{\text {hitung }} \leq \mathrm{F}_{\text {tabel }}$ maka Ho dapat diterima.

Tabel 4.3 menunjukkan bahwa nilai $\mathrm{F}_{\text {hitung }}$ adalah 21,52257 dengan tingkat signifikansi 0,000 . Sedangkan $F_{\text {tabel }}$ pada tingkat kepercayaan $95 \%(\alpha=0,05)$ adalah 2,46 . Oleh karena pada kedua perhitungan $\mathrm{F}_{\text {hitung }}>\mathrm{F}_{\text {tabel }}(21,52257>$ 2,46 ). Hal ini menunjukkan bahwa terdapat pengaruh secara simultan variabel Karakteristik Perusahaan (EPS, PBV, PER, DER) terhadap return saham dapat diterima secara keseluruhan.

Secara parsial tergambar dalam tabel 4 berikut:

\section{Tabel 4 Hasil Perhitungan Uji t}

Dependent Variable: RETURN?

Method: GLS (Cross Section Weights)

Date: 03/07/16 Time: 04:14

Sample: 20112015

Included observations: 5

Number of cross-sections used: 8

Total panel (balanced) observations: 40

Convergence achieved after 36 iterations

\begin{tabular}{|c|c|c|c|c|}
\hline Variable & Coefficient & Std. Error & t-Statistic & Prob. \\
\hline EPS? & 0.000156 & 5.86E-05 & 2.662798 & 0.0131 \\
\hline PBV? & -0.109740 & 0.042158 & -2.603085 & 0.0151 \\
\hline PER? & 0.018832 & 0.014528 & 1.296318 & 0.2063 \\
\hline DER? & -0.032933 & 0.168648 & -0.195275 & 0.8467 \\
\hline \multicolumn{5}{|l|}{ Fixed Effects } \\
\hline AT $-\mathrm{C}$ & -1.349174 & & & \\
\hline$B R-C$ & -1.276950 & & & \\
\hline ITP-C & -2.264794 & & & \\
\hline IN-C & -1.603743 & & & \\
\hline KF-C & -1.414120 & & & \\
\hline$-\mathrm{TBB}-\mathrm{C}$ & -1.463375 & & & \\
\hline$-\mathrm{TI}-\mathrm{C}$ & -2.197427 & & & \\
\hline UI-C & -0.156845 & & & \\
\hline \multicolumn{5}{|l|}{ Weighted Statistics } \\
\hline R-squared & 0.914975 & \multicolumn{2}{|c|}{ Mean dependent var } & 1.312440 \\
\hline Adjusted R-squared & 0.872463 & \multicolumn{2}{|c|}{ S.D. dependent var } & 2.173904 \\
\hline S.E. of regression & 0.776352 & \multicolumn{2}{|c|}{ Sum squared resid } & 15.67078 \\
\hline F-statistic & 21.52257 & \multirow{2}{*}{\multicolumn{2}{|c|}{ Durbin-Watson stat }} & 2.409170 \\
\hline Prob(F-statistic) & 0.000000 & & & \\
\hline \multicolumn{5}{|l|}{ Unweighted Statistics } \\
\hline R-squared & 0.408258 & \multicolumn{2}{|c|}{ Mean dependent var } & 0.696500 \\
\hline Adjusted R-squared & 0.112387 & \multicolumn{2}{|c|}{ S.D. dependent var } & 0.824041 \\
\hline S.E. of regression & 0.776356 & \multirow{2}{*}{\multicolumn{2}{|c|}{ Sum squared resid }} & 15.67094 \\
\hline Durbin-Watson stat & 2.980019 & & & \\
\hline
\end{tabular}

Sumber: Output Evies. 
Setelah melakukan pengujian di atas dapat disimpulkan bahwa model yang diajukan di dalam penelitian ini yang diuji dengan metode regresi berganda dengan metode fixed effect, Pengujian ini untuk melihat signifikansi model serta tingkat pengaruh antara variabel yang diteliti. Pengujian model ini digunakan untuk menguji hipotesis yang diajukan di dalam penelitian. Dari tabel coefficient perhitungan Uji t di atas maka model regresi yang dapat dibentuk.

\section{Hasil}

Pengujian yang dilakukan di atas terhadap model menunjukkan bahwa model yang diajukan secara signifikan membuktikan adanya pengaruh secara simultan Karakteristik Perusahaan (EPS, $P B V, P E R, D E R$ ) terhadap return saham. Pengaruh ini tidak terlalu besar jika ditinjau dari koefisien determinasi yang hanya berada di sekitar 87,23\%. Hasil penelitian ini tidak sejalan dengan berbagai penelitian di pasar modal sebelumnya bahwa hubungan yang kuat antara analisis fundamental dan analisis teknikal dengan return saham tidak secara kuat dan nyata. Hal ini karena model yang dilakukan berbeda dan model dalam penelitian ini lebih baik dari hasil sebelumnya. Hasil yang diperoleh sering tidak konsisten sehingga tidak dapat ditarik kesimpulan yang jelas.

Hasil yang tidak konsisten ini merupakan indikasi bahwa memang tidak terdapat pola yang kuat terkait dengan masalah ini. Faktor penyebab yang sering diduga menjadi penyebab hal ini adalah masalah rentang waktu dari informasi akuntansi yang diumumkan telah terlebih dahulu diprediksi oleh investor. Keadaan tersebut menyebabkan efek dari informasi akuntansi sering bukan pada periode yang sama dengan return saham yang diambil sebagai data penelitian, sehingga penelitian yang dilakukan dengan memasangkan data pada interval waktu yang sama tidak dapat membuktikan hubungan yang signifikan. Secara parsial tidak ada satu variabel-pun yang menunjukkan bahwa terdapat variabel yang memberikan pengaruh positif return saham.

\section{PENUTUP}

Berdasarkan hasil analisis data serta pembahasan yang dilakukan pada bagian sebelumnya, maka penelitian ini menghasilkan beberapa kesimpulan sebagai berikut:

1. Secara simultan variabel Karakteristik Perusahaan (EPS, PBV, PER, DER) terhadap return saham dapat diterima secara keseluruhan dimana nilai $\mathrm{F}_{\text {hitung }}$ adalah 21,52257, dengan tingkat signifikansi 0,000. Sedangkan $\mathrm{F}_{\text {tabel }}$ pada tingkat kepercayaan 95 $\%(=0,05)$ adalah 2,34 . Oleh karena pada kedua perhitungan $\mathrm{F}_{\text {hitung }}>\mathrm{F}_{\text {tabel }}(21,52257$ $>2.34$ ), hal ini memberikan kesimpulan yang mendukung penelitian berbagai penelitian sebelumnya.

2. Secara parsial menunjukkan variabel yang terdiri dari EPS $\left(\mathrm{X}_{1}\right)$, PBV $\left(\mathrm{X}_{2}\right)$, berpengaruh terhadap return saham dengan tingkat signifikansinya di bawah 0,05. Dengan demikian daerah penerimaan hipotesis berada di luar daerah penerimaan $\mathrm{H}_{0}$. Variabel-variabel lain yang tidak berpengaruh adalah PER $\left(\mathrm{X}_{3}\right)$ dengan signifikansi 0,2063 dan DER $\left(\mathrm{X}_{4}\right)$ dengan signifikansi 0,8467. 


\section{DAFTAR KEPUSTAKAAN}

Achsien, Inggi H. 2000. Investasi Syariah di Pasar Modal: Menggagas Konsep dan Praktek Manajemen Portofolio Syariah, Jakarta: Gramedia.

Alwi, Iskandar Z, 2003. Pasar Modal, Teori dan Aplikasi, Jakarta: Nasindo Internusa.

Ang, Robert, 1997. Buku Pintar Pasar Modal Indonesia, (Jakarta: Media Staff Indonesia.

Ardi Hamzah, 2005. Analisa Karakteristik

Perusahaan, Industri Dan Ekonomi Makro Terhadap Return Dan Beta Saham Syariah Di Bursa Efek Indonesia, (Solo : Jurnal SNA-8, 2005).

Candradewi, Susanna, 2000. Pengaruh Variabel Keuangan Terhadap Penentuan Harga Pasar Saham Perusahaan Sesudah Penawaran Umum Perdana, (Jurnal Penelitian Perspektif Vol 5 No 1 Juni tahun 2000).

Dahlquist, 2006. Technical Analysis: The Complete Resource for Financial Market Technicians, Financial Times Press, 2006.

Darmaji, Tjiptono \& Fakhruddin, 2001. Pasar Modal Indonesia, Jakarta: Salemba Empat.

Daud, Abu 1990. Kitab Sunan Abu Daud, Bab Syirkah, Beirut: Darul Maktab.

Garrison, 1998. Akuntansi Manjemen, Texas : Bussiness Publikation.

H.; Wang, J, 2000. Foundations of Technical Analysis: Computational Algorithms, Statistical Inference, and Empirical Implementation. The Journal of Finance, 2000.
Harahap, Sofyan Syafri, 2010. Analisis Kritis Atas Laporan Keuangan, Jakarta:: Raja Grafindo Persada.

Hasibuan, Abdul Nasser, 2009. Analisis Karakteristik Perusahaan dan Ekonomi Makro terhadap Return Saham LQ-45 di Bursa Efek Indonesia Periode 2005-2007, Tesis, (Universitas Sumatera Utara dipublikasikan,

Herawati Hardelin, 2005. Pengaruh karakteristik Perusahaan terhadap income semothing, (Solo : Jurnal SNA-8, 2005).

Husnan, Suad, 2001. Dasar-dasar Teori Portofolio dan analisis Investasi, Yogyakarta: UPP AMP YKPN.

Jogiyanto, 2003. Teori Portofolio dan Analisis Investasi Edisi 2, Yogyakarta : BPFE.

Jones, Charles. P, 2004. Investments Analysis and Management, 9th edition, New York, NY: John Wiley \& Sons, Inc.

Junaldi, Hamdan, 2007. Analisis Pengaruh Faktor Fundamental Dan Kurs Valuta Asing Terhadap Return Saham Sektor Telekomunikasi Di Bursa EfekJakartaTahun 2003-2005,Skripsi,(Universitas Islam Indonesia dipublikasikan, 2007).

Kamaruddin, Ahmad 2004. Dasar-dasar Manajemen Investasi dan Portopolio, Jakarta: Rineka Cipta.

Koetin, L.A, 1994. Analisis Pasar Modal, Jakarta: Pustaka Sinar Harapan.

Lubis, Ade Fatma 2008. Pasar modal, Jakarta : FEUI.

Mankiw, Rommer, 1995. Weil, Quarterly Journal of Economics:, 1992, hal. 407-437, Data IMF 
JURNAL IMARA

juga menunjukkan hal yang sama (IMF, World Economic Outlook:, 1995).

Pandji Anoraga dan P Pakarti, 2001. Pengantar Pasar Modal, Jakarta: Rineka Cipta.

Prastowo, Dwi \& Yuliaty, Rifky, 2000. Analisis Laporan Keuangan Konsep dan Aplikasi. Yogyakarta: UPP AMP YKPN.

Rangkuti, Freddy, 2001. Teknik Membuat Perencanaan Bisnis dan Analisis Kasus, cetakan ketiga, Jakarta: Gramedia Pustaka Utama.
Riyanto, Bambang, 1999. Dasar-dasar Pembelanjaan Perusahaan.(Yogyakarta :: BPFE.

Taddelilin, Eduardus, 2001. Analisis Investasi dan Manajemen Portfolio, Yogyakarta: BPFE.

Tjiptono, Darmadji, dan Hendy M Fakhrudin, 2008. Pasar Modal di Indonesia, Pendekatan Tanya jawab, Cetakan Ketiga, Jakarta: Salemba Empat. 